\title{
ENFORCEABILITY OF ENVIRONMENTAL RIGHTS: A POSSIBLE PANACEA TO MAN'S ENVIRONMENTAL IMBROGLIO - NIGERIA'S NIGER-DELTA AS A CASE STUDY
}

\author{
Olayinka Oluwamuyiwa Ojo- \\ O. P. Jindal University, India
}

\begin{abstract}
This research examines the potential of a human rights-based approach to address the environmental problems affecting Nigeria's Niger Delta and the world at large. This research critically assesses the various environmental legislation and policies in Nigeria, and interrogates why, despite the enactment of an environmental provision in Section 20 of the Constitution, gross environmental injustice has occurred in the country. Further discussion on the methods and strategies that can be used to guarantee access to the Court, as well as enforcing the right to a healthy environment in Nigeria, despite the current provision of the Constitution, are elucidated. This research argues that a constitutionally enforceable right to a healthy environment, a full implementation of the African Charter on Human and Peoples' Rights, the establishment of Environmental Courts and Tribunals (ECT), comprehensive and quantitative environmental citizen education, as well as the empowerment of environmental NGOs, may be the solution to the environmental challenges currently faced in Nigeria's Niger Delta as well as the entire country.
\end{abstract}

\section{Introduction}

The impact of climate change, global warming, and loss of biodiversity on the environment are obvious and constitute a massive threat to both present and future generations. These environmental problems can be traced to several human activities. The awareness of these human activities necessitated the development of environmental law at both national and international levels. This development, particularly the link between human rights and the environment, was a notable development of the late 2 oth century. It is clear today that the degradation of the environment could lead to the abuse of individual human rights, which include but are not limited to, the right to life, health, housing, prop- 
erty, culture, and equality before the law. The linkages between human rights and the environment are multi-dimensional and reciprocal and advancing goals in one field has the potential to promote the achievement of goals in the other. In the same vein, when human rights protect human life, the relationship between human life and the environment needs to be taken in to account.

It is imperative to protect the environment as well as the right that depends on it if sustainable development is to be achieved. In order to achieve this, several countries across the globe are currently applying the rights-based approach to environmental protection, a trend that has been termed the 'environmental rights revolution'. In order to understand and appreciate these developments it is essential to take a critical look at the connections and linkages between the environment and human rights, and the interpretations and decisions made by various international and regional courts and tribunals. It is also essential to consider the extent to which states are obligated to respect human rights outside their jurisdiction and territories. Other questions worth considering include: whether human rights could be applied extra-territorially in order to seek redress in cases of transboundary environmental harm? Whether and how constitutional incorporation of environmental rights and protection provisions could help protect human rights and the environment following environmental degradation? The accessibility and justiciability of environmental rights and protection provisions, and how they could be better improved to guarantee the protection of the rights to a healthy environment?

\section{Research objectives and motivation}

This study aims to examine in detail the development of international environmental human rights as well as the linkage between human rights and the environment. We will examine the approach of international, regional, and national institutions towards the emergence of environmental rights, the greening of existing human rights in order to prevent environmental degradation and protect the environment, as well as identifying those human rights that are violated as a result of environmental degradation. The primary aim of this work is to highlight the new trend of enacting environmental rights or provisions in Constitutions, the possibility of enforcing such Constitutional environmental rights or provisions and the effect of such enforceability. This work will be a valuable contribution to efforts to solve the environmental imbroglio confronting humanity today, with emphasis on Africa and particularly Nigeria. The key environmental provisions in the Nigerian Constitution are assessed in this research. Focusing primarily on Nigeria's Niger Delta region, the research examines the activities of oil conglomerates, violations and the impacts of their activities on the communities in which they operate, as well as the government's failure to respect, protect and fulfil relevant environmental rights. The duties of the people as enshrined in the constitution and the rationale behind the government's failure are equally examined. Furthermore, the study examines whether the enforceability of a Constitutional environmental right could be a panacea to the environmental problems in Nigeria. 
The continuous rise in the destruction of the environment despite the inclusion of environmental provisions in several countries' constitutions necessitates this study. The main question this research intends to answer is: how does constitutional incorporation of environmental rights and protection provisions help in the protection of the environment as well as protecting the rights of those breached as a result of environmental degradation? The case study will be the people in the oil-producing communities of Nigeria whose environment has deteriorated more since the introduction of section 20 of the I999 Constitution of Nigeria. Accordingly, this research will also aim to answer the following questions:

- How adequate is the legal framework for environmental rights on the international and regional scene as well as in Nigeria?

- To what extent are states obligated to respect human rights outside of their jurisdiction and territories? Can human rights be applied extra-territorially as a means to seek redress in cases of transboundary environmental harm?

- How accessible and justiciable are the environmental rights and protection provisions, and how might they be improved in order to guarantee the protection of the rights to a healthy environment?

\section{Methodology}

This research relies on primary and secondary sources of law. Primary sources include conventions or treaties, constitutions, legislation, and court decisions at the international, regional, and national levels. Furthermore, secondary sources such as textbooks, articles, journals, newspapers, periodicals, magazines, publications, reports, dissertations, theses, and other relevant materials from the internet are relied upon. Previous research findings, opinion surveys, and special publications on the subject by scholars, local NGOs, and international human rights NGOs etc. are studied. Furthermore, the research of archives of the Social and Economic Rights Action Centre (SERAC) was also used. As the research transcends the discipline of law to other fields such as the social sciences and the natural sciences, the doctrinal approach intersperses with interdisciplinary and legal approaches. The research is not limited to legal texts and decided cases but extends to methods from other disciplines.

\section{The conceptual and theoretical framework of the research}

Human activities on Earth have been said to have triggered several cataclysms facing our environment today. Researchers and policy-makers on environmental issues have opined that the plethora of human activity has increased pressure on the environment, pressures that can no longer be sustained by the environment. ${ }^{2}$ According to David Hunter, these are "wild facts" that our generation must confront through environmental law and policy. These cataclysms are climate change, stratospheric ozone depletion, loss of biodiversity, and environmental contamination by hazardous chemicals and waste. 
Society has responded to this global environmental cataclysm with initiatives on every scale, from the global to the local stage. Several international environmental conferences, meetings, and dialogues have been convened, which has brought into existence several treaties, conventions, and declarations covering all of the environmental issues facing humanity, including, climate change, ozone depletion, destruction of marine ecosystems, loss of biodiversity, air and water pollution, trade in hazardous substances, trade in endangered species, and persistent organic pollutants. Several institutions, policies, standards, rules, and regulations were created, formulated and enacted. The development of international environmental law, and particularly environmental human rights as a distinctive legal regime, was a notable development of the late 2oth century. Specifically, one of the policies formulated at the international level, is the right to live in a healthy environment. According to Martin Shapiro, "as the cold war ended, two great secular religions have come to grip the world: environmentalism and human rights." 3

Due to this development on the international stage, several countries have also taken steps to develop environmental legal frameworks within their territories. Currently, I87 of the UN's 193 member states have recognised this right, either through their Constitution, environmental legislation, court decisions, or ratification of an international agreement. ${ }^{4}$ The continuous promulgation of these environmental provisions in various constitutions is a positive step. However, mere introduction without enforceability or justiciability, as described by Olowu, are "worthless platitudes." ${ }^{5}$ Notably, this reflects the current situation in Nigeria given the non-justiciability of section 20 of the country's Constitution. Although, Nigeria has not embraced this global trend, it is, nevertheless, well-placed to learn from the experiences of other countries that have started to integrate versions of these concepts into their legal systems.

The primary rationale for this research is to examine the potential opportunities that the rights-based approach could offer in the protection of the human environment. It can be stated, based on this research, that the rights-based approach is capable of addressing many of the environmental challenges facing the world today. In Chapter I of this research, a general overview of the environment - definition, components, and importance - was examined; this helps in understanding the fragility of the environment and why a coherent strategy must be adopted to protect it. It argues that our environment is global commons, and no one has a monopoly on the environment. UNEP has already identified the high seas, the atmosphere, Antarctica, and the outer space as global commons. It was, however, argued that no part of the environment could either be isolated or separated from other parts; they are all interwoven. Our ecosystem is so interconnected that an action taken in any part of it will affect other parts. This research further argued that the ecosystem has existed for a very long time as global commons before any attempt to formalise its political properties. Political properties such as territories, borders, and the laws relating to the same may not change the settled fact that our earth and the ecosystem

3 Shapiro, 1992

4 UNEP, 2019: 2

5 Olowu, 2006: 56-6o 
is global commons. In conclusion, it argues that the real global common is not a place or space as identified by several authors and scholars; instead, it is a system.

Chapter 2 examines the environmental crises degrading the earth today, which are climate change, ozone layer depletion, and loss of biodiversity. It also considers several factors causing climate change, such as galactic variation, orbital variation, solar variation, orogeny, epeirogeny, volcanic eruption, ocean circulation, and atmospheric composition. It further examines several conferences, summits, discussions, and meetings that deliberated and proposed solution to these environmental crises such as the Stockholm Conference (1972), the Rio Earth Summit (1992), the Johannesburg Earth Summit (Rio+Io, 2002), the United Nations Conference on Sustainable Development (Rio+20, 20I2), the Brundtland Commission Report - Our Common Future (I987), the Rio Declaration on Environment and Development (I992), Agenda 2I (I992), the Convention on Biological Diversity (I992), the ICPD Programme of Action (I994), the Lisbon Principles (1997), the Earth Charter (2000), the UN Millennium Declaration (2000), the Sustainable Development Goals (2015), and Paris Agreement (2016). These conferences and summits led to the development of environmental law both at the international and national levels. This chapter also looks into the various approaches used by countries in incorporating environmental law into their legal system. We examine three types of approaches, i.e., the mandatory approach, which is also known as the Command and Control approach; the non-mandatory approach, divided into a non-mandatory voluntary approach and an economic incentive approach; and finally, the human rights or rights-based approach. Further, it performs a critical study of the rights-based approach, the advantages, development as well as how the approach helps in tackling environmental degradation.

Chapter 3 examines the connection between the environment and human rights. It examines several instruments on human rights and the environment, in order to have a better understanding of the connection between them. It also examines how provisions in human rights treaties affect the environment and how provisions in environmental treaties affect human rights as well as identifying specific human rights that could be breached, affected, and threatened as a result of environmental degradation. Human rights such as the right to life, the right to food, the right to health, the right to property/adequate housing, the right to private and family life, and the prohibition of torture, inhuman or degrading treatment, are specifically examined. The status of the right to a healthy environment in international law as well as the position of several regional human rights institutions, suggest that the right to a healthy environment is yet to receive explicit recognition under the international bill of rights. We argue that one of the main reasons for this is because the precise content of the right and the obligations it imposes on states are not yet explicit. Several limitations associated with the recognition of the right to a healthy environment were outlined, including the fact that the obligations imposed by the right may merely be duplicating the existing obligations under international environmental law and international human rights law. The following questions were also examined: Whether the right to a healthy environment is a human right or not? Whether the right to a healthy environment is an individual right or collective right? Whether the right is procedural or substantive in nature. The chapter argues that national recognition 
of the right to a healthy environment is important, and for proper enforcement of the right in national contexts, adoption of constitutional measures is necessary. It outlines several options for constitutional recognition of the right and identified the trends in several countries. It further lists a set of potential benefits that would accrue if the right is constitutionally recognised, such as increased prioritisation of environmental protection, considerations in government decision-making, and increased avenues to bring legal actions in the interests of environmental protection. It further argues that in order to adequately protect the rights of environmental degradation victims at the international and national levels, it is pertinent to recognise this right to a healthy environment as well as constitutionalise it. ${ }^{6}$

Chapter 4 examines the application of environmental rights to extra-territorial environmental issues. Proper consideration of environmental degradation would not be complete without considering the extra-territorial effect of the hazardous activities of multinational corporations, companies as well as activities approved by the state. Because this research seeks rights-based solutions to environmental challenges, it is pertinent to look into the current position of international law and the application of human rights on extra-territorial issues. In order to understand the position of international law on these issues, judicial interpretations of jurisdiction and the possibility of extending the jurisdiction of a state under international conventions, such as the ICCPR, ICESCR, ACHR, ACHPR, CAT, ECHR and CRC are examined. This chapter further argues that due to the strict interpretation of the doctrine of effective control in civil and political rights on extra-territorial issues, it might be challenging to apply this principle to environmental issues. It was, however, also stated that because the ICESCR did not mention jurisdiction, economic, social, and cultural rights can be applied extra-territorially. In supporting this, the CESCR identified four types of extraterritorial duties of a state party, namely, a) non-interference with the enjoyment of human rights in other countries; b) putting measures in place to secure and prevent private actors from interfering with the enjoyment of human rights in other countries; c) to take all necessary steps through aid and co-operation in ensuring the fulfilment of human rights in other countries; d) to ensure that international agreements do not adversely affect human rights. Also, there is lack of well-structured models in both international environmental law and international human rights law that allow for the enforcement of extra-territorial environmental rights. The chapter goes on to argue that although the recognition of extra-territorial environmental rights is unlikely to occur soon, some environmental rights frameworks within general international law, such as the Aarhus Convention, have mitigated this lacuna by creating platforms where hazardous environmental activities of an extra-territorial nature can be reported and addressed.

Chapter 5 examines the emergence of Environmental Courts and Tribunals (ECT) at the domestic level. It argues that the adoption of legal norms and policies without a wellstructured means of enforcement has little added value. It argues that several environ- 
mental cases filed at the conventional courts face several challenges such as procedural bottlenecks, delays in trials, lack of competent judges in environmental matters, and cost. It further argues that due to the importance of the environment and the urgency needed to ensure its protection, to guarantee environmental justice as well as the enforcement of the rights of victims of environmental degradation, it is pertinent to establish environmental courts and tribunals. It examines the advantages of ECT, such as expertise, efficiency, low cost, access to court, speedy trials, prioritisation of environmental matters, judicial activism, and commitment. It also highlights the disadvantages, such as fragmentation, insufficient caseload, public confusion, judicial activism, marginalisation of environmental cases and a host of other issues. The emergence of ECT in Africa is examined, with emphasis on Kenya's ECT. It considers the structure of Kenya's ECT, the power of the court, and the enforcement mechanism of its decision. Finally, best practices from around the world, especially the example of Kenya, are recommended to African countries.

Chapter 6 examines the environmental legal framework in Nigeria and the way forward in ensuring access to courts and adequate enforcement of the right to a healthy environment. It focuses on Nigeria's Niger Delta - one of the most exploited communities on earth. It considers relevant environmental legislation in the country as a framework for subsequent analysis. It argues, however, that several of the laws in Nigeria are inadequate or outdated. This research places more emphasis on Section 20 of the Constitution, which is the main provision dealing with the protection, conservation, and preservation of the environment. Judicial decisions and interpretations linked to this provision generally affirm the non-justiciability of the right to a healthy environment; this leaves victims in highly vulnerable situations. The chapter argues that environmental matters in Nigeria could be justiciable if the current human rights provisions in Chapter 4 of the Constitution can be used and applied on environmental matters rather than placing emphasis on, and solely relying on, Section 20 of the Constitution.

Similarly, we argue that the content of Article 24 of the African Charter on Human and Peoples' Rights (ACHPR), which provides for the right to an environment favourable to development, has been ratified and domesticated in Nigeria. In this regard, the I999 Fundamental Rights Enforcement Procedure Rules stipulate that Article 24 ACHPR is one of the human rights' laws enforceable in Nigeria. Accordingly, victims of environmental degradation can institute legal action based on this provision of the African Charter rather than relying on the provision of Chapters 2 of the Constitution. Furthermore, the chapter examines the possibility of establishing environmental courts and tribunals in Nigeria, which will be a court of record recognised under Section 6 of the Constitution and given all the necessary apparatus to enable environmental justice in Nigeria. It argues that the establishment of such a court is vital due to the constant pollution and oil spillages, delays in trials on environmental issues, lack of judges with environmental knowledge, high cost of prosecuting cases in Nigeria, and constant dismissal of several environmental cases based on lack of standing. 


\section{Implications of the research for legislation, policy, and practice}

This research sought to respond to several questions relating to the effect of environmental human rights in solving the environmental problems confronting the world today, particularly Nigeria's Niger Delta. Broadly speaking, there are several implications for legislators, the judicial system, decision-makers, administrators and policy-makers in ensuring that all and sundry enjoy a healthy environment free from pollutants and hazardous chemicals; ensuring due compliance with environmental procedures, laws, and policies; and access to court on environmental matters.

One of the issues identified as prompting persistent environmental degradation in the Niger Delta is the inadequate legal framework governing environmental matters. It, therefore, behooves legislators and policy-makers to ensure that necessary legal frameworks are put in place to protect the environment and the victims of environmental degradation adequately. The suggestions and proposals in this research regarding the gaps in the legal framework are to help decision-makers to take necessary steps in reforming the existing laws and policies to ensure that the environment is adequately protected and to prevent the violation of each citizen's right to a healthy environment. This research will help legislators and policy-makers understand the fragility of the environment, why urgent action is needed to protect it, as well as the need to put necessary machinery in place, such as establishing new institutions as well as strengthening existing institutions and agencies, to deal with environmental issues and degradation promptly. In the same vein, this research will help legislators and policy-makers to understand the vital role of public participation and access to court on environmental issues as the most effective method in ensuring the protection of the environment. Therefore, the adoption of relevant legal norms and policies could promote and enhance citizen education on environmental issues, which will, in turn, empower citizens with the necessary information to partake in the decision-making process on environmental issues, as well as enable them to defend their rights when breached.

Similarly, this research could help the courts as well as the judicial system, which is regarded as the last hope of the common man, to better adjudicate environmental cases, with a high level of professionalism and knowledge. Furthermore, it makes the courts accessible to victims of environmental degradation or those who are protecting the rights of victims of environmental degradation. This research may also serve as a tool for the Nigerian judiciary to understand the global trends regarding the right to a healthy environment and how courts in other countries are greening the existing human rights to ensure the environment is protected as well as protecting the rights of victims of environmental degradation. Additionally, this research could further highlight the need to build the human and institutional capacity of the judiciary, for judges and other judicial actors, for effective delivery of justice on environmental matters in Nigeria.

In addition, this research could help citizens and victims of environmental degradation in Nigeria to understand the legal framework regulating environmental issues, as well as help them in taking necessary steps in seeking relief for damage done to their environment by state and non-state actors. It could also help victims and NGOs to find ways around the current non-justiciability of section 20 of the constitution, as well as the 
constant refusal of the courts to adjudicate on environmental matters by striking them out on technical grounds or jurisdictional grounds. Multinational corporations and other private entities could also be better informed of the importance and fragility of the environment, while taking into account the human rights implications of their activities.

Furthermore, this research could help African countries to restructure their environmental law jurisprudence by enacting laws to protect the environment and establishing environmental courts and tribunals, which will help in adjudicating environmental matters efficiently and promptly. Finally, this research aims to contribute to the development of international environmental law and the furtherance of the right to a healthy environment globally.

\section{Conclusion}

In conclusion, the prevention of environmental harm requires far more than governmental actions. NGOs, independently or in partnership with the government, must operate and co-operate together to improve the environmental performance of individuals and businesses. There should be increased public enlightenment to create awareness of the need for protection of the environment with all citizens as stakeholders. This research argues that human rights may not be a sufficient condition for environmental sustainability, but that an empathetic concern for the fate of others, informed by knowledge of both the social and ecological embeddedness of human life, provides a coherent link between environmental sustainability and human rights in the context of globalisation. Although environmental harm may not be eliminated completely, its overall incidence and impact will be much less. There should be closer collaboration between the various tiers of government to ensure a co-ordinated enforcement of environmental laws.

Environmental policies, legislation, and laws without a proper mode of enforcement or a well-equipped judiciary will not help citizens. The best environmental standards in the world will be ineffective if they are not complied with or adequately enforced. Compliance and enforcement ensure good environmental governance and respect for the rule of law. Equally, they determine the compatibility of environmental standards with practical realities and provide a yardstick for assessing whether the standards should be maintained, amended, or repealed. Standards and environmental impact assessments require strong political will, significant legislative changes, stakeholder co-operation, and substantial human and technical resources.

Furthermore, reforms of instruments of direct regulation can be successful only if they are integrated and an appropriate balance is struck between what is desirable from an environmental point of view and what is possible from a technical and economic point of view. The institutions charged with the responsibility of enforcing environmental law have much to do in this area. Where these institutions fall short of minimum standards, then the objectives for enacting laws to protect the environment may never be met. Furthermore, enforcement of the right to a healthy environment will encounter substantial setbacks without a well-structured court system empowered to administer justice on environmental issues. Environmental courts and tribunals are pivotal in ensuring environmental justice for all and sundry. Kenya's Environmental Courts have proven not only 
the importance, but also the possibility of establishing ECTs in Africa; and hopefully, other African countries could learn from the experience of Kenya. The case study of $\mathrm{Ni}$ geria's Niger Delta studied in this research shows how environmental degradation can lead to a breach of human rights. After due consideration of a plethora of legislation in Nigeria which deals with environmental issues and the non-justiciability of Section 20 of the Constitution, environmental courts are germane in ensuring due compliance with the provisions of legislation and policies protecting the environment as well as empowering victims of environmental degradation to seek adequate redress. It is important to note that a constitutionally recognised independent human right to a healthy environment which is enforceable and not a mere declaration, will go a long way in ensuring that people enjoy a healthy environment. This form of constitutional recognition of the right to a healthy environment in Nigeria has considerable potential to be an effective, albeit limited, tool for environmental protection as well as a panacea to the environmental degradation that is ongoing in Nigeria's Niger Delta, as well as in the country at large. This research has outlined the possible limitations of the right in Nigeria, which hinders its effectiveness from functioning as a tool for environmental protection.

In conclusion, much as this right has the potential to curb environmental degradation as well as serve as a tool for environmental protection in Nigeria, its general utility should not be overstated. Several structures need to be put in place in order to enable effective functioning of this right, such as tackling corruption, good infrastructure, sufficient legal framework, a well-equipped judiciary, and educated citizens. In sum, this research will significantly contribute to a national discussion regarding the emergence of the right to a healthy environment as well as innovative approaches to environmental protection, and a broader international discussion regarding the utility and the emergence of a human rights-based approach to the protection of the environment.

\section{References}

Boyd, D. (2013). The Status of Constitutional Protection for the Environment in Other Nations. The David Suzuki Foundation: Vancouver, 6.

Hunter, D. et al. (20II). International Environmental Law and Policy - 4th ed. New York: Foundation Press, 7.

Olowu, D. (2006). Human Rights and the Avoidance of Domestic Implementation: The Phenomenon of Non-Justiciable Constitutional Guarantees. Saskatchewan Law Review, 69(I): 56-6o.

Shapiro, M. (I992). The Giving Reasons Requirement. University of Chicago Legal Forum, I992(I): 8.

UNEP. (20r9). Environmental Rule of Law - First Global Report. Nairobi: UNEP, 2. 